TOMASZ KOPICZKO

UKSW WARSZAWA

ORCID 0000-0002-8000-6714

PAULINA OKŁA

CH WARSZAWA

ORCID 0000-0002-7251-8672

\title{
KATECHEZA SAKRAMENTALNA JAKO LABORATORIUM WIARY
}

\section{Wstęp}

Zgodnie z duchem odnowy soborowej Vaticanum II, Kościół, który rozumie siebie, stara się o sobie opowiadać i ukazywać piękno wiary. Jest to wezwanie do dialogu ze współczesnymi ludźmi. Zgodnie z zaleceniem Pawła VI, „Kościół powinien nawiązać dialog ze społeczeństwem, w którym żyje. Dzięki temu Kościół przy-


podejmuje wspólnota Kościoła staje się szkołą „cudownego, zbawczego dialogu”2.

Ukazanie się Dyrektorium o katechizacji stanowi dobrą okazję do podjęcia na nowo refleksji nad zagadnieniem katechezy sakramentalnej. Umiejscowiona między rzeczywistością szkolną i parafialną wymaga ona ciągłej refleksji i dostosowania do nowych wyzwań duszpasterskich. Propozycją niniejszego artykułu jest rozważenie zagadnienia katechezy sakramentalnej, urzeczywistniającej się w kategoriach laboratorium wiary. Jest to swoista nowość na przestrzeni myśli katechetycznej, którą proponuje dokument wydany przez Papieską Komisję ds. Krzewienia Nowej Ewangelizacji w 2020 roku.

Celem niniejszego artykułu jest podjęcie refleksji nad zagadnieniem katechezy sakramentalnej, realizowanej w „strategii laboratoryjnej”. Zagadnienie katechezy sakramentalnej jest rzeczywistością znaną i badaną w myśli pastoralnej. Zamiarem autorów jest zatem skupienie się na refleksji dotyczącej zagadnienia „laboratorium wiary”. Cel ten będzie zrealizowany poprzez zaprezentowanie współczesnego

1 Paweł VI, Ecclesiam suam, 65.

2 DK 53. 
kontekstu katechetycznego, wyjaśnienie znaczenia terminu „laboratorium wiary” oraz syntetyczną prezentację podstawowych założeń metodologicznych. Główne źródło dla podejmowanej refleksji stanowią najnowsze dokumenty katechetyczne oraz nauczanie papieży, realizujących principia odnowy soborowej.

\section{Katecheza ciągle nowa}

25 czerwca 2020 roku abp Rino Fisichella, prezentując nowe Dyrektorium, podkreślił, że wpisuje się ono w dynamikę ruchu katechetycznego, który od zawsze zajmuje znaczące miejsce w życiu wspólnoty chrześcijańskiej. Stwierdził on, że „katecheza to wielki proces, który dokonuje się w różnych dziedzinach, od liturgii po świadectwo posługi charytatywnej, od modlitwy osobistej po wymiar moralny. Chcemy jednak, aby w tym wielkim procesie katechizacji jego najsilniejszym elementem było pierwsze głoszenie Jezusa Chrystusa. (...) Dokument ten jest też próbą odpowiedzi na tę nową fazę światowej kultury. (...) To wymaga od nas lepszego kontaktu z kulturą naszej młodzieży, która urodziła się w świecie cyfrowym. Nasza formacja i pedagogia musi to uwzględnić ${ }^{3}$. Założenie to wpisuje się w prastarą zasadę Ecclesia semper reformanda ${ }^{4}$. Świadomość przynależności do Kościoła domaga się wyznawania wiary w Jezusa Chrystusa w nowych okolicznościach i wobec nowych wyzwań. Osoba Chrystusa oraz troska o wiarę pozostają niezmienne, ale sposób urzeczywistniania ludzkich myśli na temat Pana Boga podlega ciągłym zmianom. Vaticanum II za św. Augustynem określa wspólnotę Kościoła mianem „pielgrzymującego Ludu Bożego" . Widocznym znakiem tej pielgrzymki wiary jest nieustające poszukiwanie ciągle nowych modeli duszpasterskich.

Praktyka duszpasterska XIX i XX wieku pokazała, że przygotowanie katechetyczne do sakramentów, oparte jedynie o „suchą” prezentację doktryny, nie jest wystarczająco skuteczne. Być może tak zrealizowana katecheza sakramentalna jest w stanie na chwilę zagłuszyć sumienia odpowiedzialnych za wychowanie w wierze. Z całą pewnością jednak nie prowadzi ludzi do żywej wiary oraz dynamicznego życia sakramentalnego. Jak zauważa F. Blachnicki, swoisty „intelektualizm katechetyczny, charakterystyczny dla drugiej połowy i końca XIX wieku, praktycznie do dzisiaj pokutuje w naszej katechezie"6.

\footnotetext{
3 R. Fisichella, Nowe dyrektorium o katechizacji: więcej ewangelizacji, w: https://www.vaticannews. $\mathrm{va} / \mathrm{pl} /$ watykan/news/2020-06/dyrektorium-o-katechizacji.html [dostęp 14.06.2021].

4 M. Rojek, Ecclesia semper reformanda, „Resovia Sacra. Studia Teologiczno-Filozoficzne Diecezji Rzeszowskiej" 3(1996), s. 25-37; Y. Congar, Prawdziwa i fałszywa reforma w Kościele, Kraków 2001, s. $37 \mathrm{nn}$.

5 Por. LG 8.

6 F. Blachnicki, Sympatycy czy chrześcijanie?, Kraków 2008, s. 74.
} 
Pozytywnym zjawiskiem w duchu odnowy soborowej stała się propozycja katechezy kerygmatycznej, antropologicznej lub różnych jej wariantów. Zwrócenie uwagi na jasny przekaz, odbiorcę oraz kontekst pozwoliło zatroszczyć się o klimat celebratywności i przeżyciowości. W różnych kontekstach religijnych i kulturowych pojawiały się konkretne propozycje katechezy, opartej o doświadczenie i aktywne nauczanie ${ }^{7}$. Należy także podkreślić wzrost świadomości co do faktu, że cała wspólnota jest odpowiedzialna za katechezę ${ }^{8}$. Czas pontyfikatu Jana Pawła II, Benedykta XVI oraz papieża Franciszka to próba poszukiwania człowieka i przywrócenia mu sensu życia ${ }^{9}$. Niejednokrotnie podejmowane są też wysiłki na poziomie duszpasterskim, aby katecheza stała się szkołą komunii dla wspólnoty Kościoła ${ }^{10}$.

Przełomowym krokiem między propozycją Vaticanum II a współczesnością jest zachęta Benedykta XVI, aby nie tylko poznać Jezusa Chrystusa na płaszczyźnie wydarzenia historycznego, przyjmując postawę anonimowego chrześcijanina. Istotą tego spotkania powinna stać się osobowa relacja i przyjęcie Chrystusa jako Boga, który stał się Słowem ${ }^{11}$. Jednak wobec dynamizmu przemian społecznych, zachodzących zwłaszcza w drugiej połowie XX i na początku XXI wieku, koniecznym wydaje się być zastosowanie propozycji Dyrektorium o katechizacji z 2020 roku. Pragnieniem Kościoła jest to, aby posługa katechetyczna przyjęła dialogiczny styl. $\mathrm{W}$ ten sposób jeszcze lepiej ma ukazywać oblicze Chrystusa ${ }^{12}$.

W ten sposób zarysowuje się dynamiczny kształt głoszenia, uświęcania i pasterzowania. Cała posługa Kościoła jest zatem rzeczywistością bogatą, wielostronną oraz dynamiczną ${ }^{13}$. Łącząc swoje wielorakie możliwości, Kościół urzeczywistnia się w dawaniu świadectwa, głoszeniu Słowa, sakramentach. Wszystkie te elementy mają doprowadzić do wewnętrznej przemiany ${ }^{14}$. Zatem katecheza sakramentalna to nie tylko wychowanie do wiary, ale zachęta do praktykowania miłości względem Boga i człowieka. Na drodze ewangelizacji, a następnie katechizacji, uczeń Chrystusa powinien stać się gotowym do wyznawania wiary. Sprawowane sakramenty „zaszczepiają w Chrystusie”, oczyszczają i oświecają na drodze życia ${ }^{15}$.

Jak zauważa dokument, we współczesnym świecie dzieje się tak, że ci, którzy proszą o łaskę sakramentów lub już ją nawet otrzymali, często nie mają „doświadczenia

\footnotetext{
Por. B.R. Hill, Key Dimensions of Religious Education, Winona Minnesota 1988, s. 55-56.

8 Por. J. Dunlap, Practical catechesis, New York 2001, s. 49-54.

9 Por. J.A. Pagola, Percorsi di evangelizzazione, Bologna 2018, s. 11-20.

10 Por. B. Körner, Fusione di testimonianza e testimone nella comunione dei testimoni. Conoscenza nella fede a spiritualità della comunione, w: M. Sodi, Il metodo teologico. Tradizione, innovazione, comunione in Cristo, Citta del Vaticano 2008, s. 381-395.

11 Por. Benedykt XVI, Przedmowa, w: Tenże, Jezus z Nazaretu, cz. 1, Kraków 2007, s. 5-15.

12 Por. DK 53-54.

13 Por. EN 17.

14 Por. DK 16.

15 Por. tamże 34.
} 
wiary lub nie są w zażyłości z jej siłą i ciepłem"16. Także formalne głoszenie, ograniczone często do wyjaśnienia pojęć, związanych z wiarą, nie stanowi autentycznej formuły katechezy sakramentalnej. Nie pozwala także na zrozumienie wiary w kategoriach „nowej perspektywy życia, otwierającej się na oścież, dzięki spotkaniu z Panem Jezusem"17.

\section{Doświadczenie Boga w „laboratorium”}

PastoralnastrategiaJana Pawła II, realizowana wramach Światowych Dni Młodzieży zakładała, że posługa zbawcza Kościoła ma stać sięwspółczesną szkołą wiary. To właśnie w czasie Światowych Dni Młodzieży w 2000 roku Jan Paweł II po raz pierwszy zaprosił młodzież do rzeczywistości, którą nazwał „laboratorium wiary" ${ }^{\text {. }}$. Zaproponował młodzieży, aby przeżywali swoją relację z Chrystusem na wzór „«laboratorium wiary», z którego apostołowie wyszli jako ludzie w pełni świadomi prawdy, jaką Bóg objawił w Jezusie Chrystusie - prawdy, która miała ukształtować ich życie osobiste i życie Kościoła na przestrzeni historii. Dzisiejsze rzymskie spotkanie, droga młodzieży, jest również swego rodzaju «laboratorium wiary» dla was, dzisiejszych uczniów - dla wyznawców Chrystusa na progu trzeciego tysiąclecia"19. Skierowana do młodych propozycja papieża miała na celu zgromadzenie ich przy Chrystusie. Głosząc Ewangelię oraz dając o Nim świadectwo, Jan Paweł II dokonał swoistej aktualizacji doświadczenia wiary w całej panoramie różnorodności wymiarów Kościoła powszechnego ${ }^{20}$.

Dyrektorium o katechizacji, proponując katechezie, aby przyjęła postać laboratorium opartego o dialog, odwołuje się do spotkania Chrystusa z Samarytanką przy studni. Jak podkreśla dokument, istotą tego wydarzenia jest zatrzymanie się Jezusa, aby porozmawiać z każdym człowiekiem i doprowadzić go do sytuacji, w której odkrywa prawdziwą wodę żywą (por. J 4, 5-42). Także dzisiejsza katecheza, w tym również, jak zostało zaakcentowane w powyższych akapitach, katecheza sakramentalna, napotyka na człowieka żyjącego w złożonych i skomplikowanych sytuacjach. Przypomina Samarytankę, do której Jezus mówi przy studni. Współczesny człowiek w całym swoim zagubieniu nadal jednak ma pragnienia i poszukuje. Sytuacje egzystencjalne stawiają często ograniczenia, czasem prowadzą także do podejmowania błędnych decyzji. W takim właśnie kontekście posługa

\footnotetext{
16 DK 56.

17 Tamże.

18 Jan Paweł II, Nie lękajcie się zawierzyć Chrystusowi. Przemówienie wygłoszone podczas czuwania modlitewnego w Tor Vergata 19 sierpnia 2000, w: https://opoka.org.pl/biblioteka/W/WP/ jan_pawel_ii/przemowienia/tor_vergata_19082000.html [dostęp 14.06.2021].

19 Tamże.

20 Por. M. Mendyk, Fenomen Światowych Dni Młodzieży - świadectwo ze spotkania młodych w Madrycie, „Wrocławski Przegląd Teologiczny” 20(2012)1, s. 123-134.
} 
katechetyczna powinna stworzyć warunki laboratoryjnego spotkania. Używając terminu „laboratoryjny” nie należy jednak utożsamiać go z warunkami „sterylnymi”, gdyż takie w rzeczywistości nie istnieją. Chodzi raczej o miejsce, w którym dokonuje się dobrowolne i bezinteresowne doświadczenie spotkania rozmówców. Być może nawet nie zobowiązuje, ale w sposób stopniowy ma prowadzić do rozwoju. Dialog ten w obecnych czasach dokonuje się nie tylko z pojedynczym człowiekiem, ale z całym społeczeństwem, kulturą oraz nauką. Musi być on pozbawiony relatywizmów. Nie może kwestionować chrześcijańskiej tożsamości. Jego pragnieniem jest jednak dotarcie do serca drugiego człowieka, aby zasiać tam ziarno Ewangelii ${ }^{21}$.

Najważniejszą kwestią w katechezie sakramentalnej, realizowanej w kluczu laboratoryjnym, jest rozbudzenie i pogłębianie wiary osoby, przyjmującej sakrament. Bez wiary sakramenty stają się jedynie zewnętrznym znakiem, często niezrozumiałym. Na kolejnych etapach życia doświadczenie Boga oraz relacji z Nim powinno mieć charakter dynamicznego procesu, zmierzającego w kierunku rozwoju. Łaska Boża, która umacnia naturę człowieka winna prowadzić w kierunku świętości. Sakramenty chrześcijańskiego wtajemniczenia kładą fundament dla życia wiarą ${ }^{22}$. Człowiek narodzony przez chrzest jako dziecko Boż $\mathrm{e}^{23}$ zostaje umocniony poprzez dary Ducha Świętego ${ }^{24}$, a w Eucharystii otrzymuje pokarm na życie duchowe ${ }^{25}$.

Kolejnym etapem są sakramenty uzdrowienia. Człowiek ze swej natury jest słaby, dlatego też „życie Boże może ulec osłabieniu, a nawet można je utracić przez grzech" ${ }^{26}$. Także na płaszczyźnie sakramentów uzdrowienia potrzebne jest człowiekowi doświadczenie żywego Boga, który staje jako Lekarz duszy i ciała. Sakrament pokuty i pojednania oraz sakrament namaszczenia chorych to momenty, które domagają się szczególnej wrażliwości i świadomości na to wszystko, co daje łaska Boga. We właściwym przeżywaniu tych sakramentów potrzeba równowagi pomiędzy emocjami a intelektem. Celem laboratorium wiary w przestrzeni sakramentów uzdrowienia jest rozbudzenie miłości do Boga oraz człowieka, prowadzącej do osiągnięcia zbawienia. To właśnie pragnienie życia wiecznego ma stać się nadrzędnym motywem podjęcia wysiłku formacji chrześcijańskiej ${ }^{27}$.

Sakrament święceń ${ }^{28}$ oraz małżeństwo ${ }^{29}$, nazywane sakramentami w służbie komunii, nastawione są na wspólnotę ${ }^{30}$. Katecheza przygotowująca i wyjaśniająca

21 Por. DK 53, 54.

22 Por. tamże, 70.

23 Por. KKK 1213.

24 Por. tamże, 1316.

25 Por. LG 11; KKK 1325.

26 KKK 1420.

27 Por. DK 64; DV 5, KKK 1457; M. Roselli, Io acolgo te. Primolaboratorio della fede, „Rivista di Pastorale Liturgica" 1(2017), s. 42-45.

28 Por. KKK 1536.

29 Por. tamże 1601.

30 Por. tamże 1534. 
znaczenie tych sakramentów w doświadczeniu bliskości Boga, prowadzi do służby braciom. W tym momencie dokonuje się uzewnętrznienie wiary, a tym samym widoczne są owoce spotkania z Chrystusem. Kluczowe wydaje się być doświadczenie liturgiczne i modlitewne, przeżywane zarówno w wymiarze indywidualnym, jak i wspólnotowym ${ }^{31}$.

A. Matteo w swojej książce Pierwsza generacja niewierzacych podejmuje temat trudności w wierze, które napotyka współcześnie żyjący człowiek. Zauważa on, że często życie człowieka rozgrywa się pomiędzy fascynacją młodością a sentymentami osób dorosłych. Pośrodku tego wszystkiego staje Chrystus, który wydaje się mówić do każdego z osobna: „Ty mnie interesujesz” ${ }^{32}$. Rolą wspólnoty Kościoła jest przekazanie współcześnie żyjącemu człowiekowi tych słów Chrystusa. W takim kontekście laboratorium wiary, w którym dokonuje się katecheza sakramentalna, ma wzbudzać w człowieku fascynację osobą Chrystusa. Jak zauważa inny włoski teolog, A. Zavattini, katecheza nie może być jedynie publikacją kolejnej książki religijnej, gdyż będzie to ucieczka w struktury szkolne i okaże się brakiem kompetencji ze strony wspólnoty Kościoła ${ }^{33}$. Człowiek w relacji do Boga ma poczuć się autentycznym protagonistą spotkania. Doświadczenie wiary, będące owocem katechezy przeżywanej w duchu laboratorium, powinno rozbudzać w człowieku pragnienie przyjmowania i przeżywania sakramentów we wspólnocie Kościoła, dawać poczucie nadprzyrodzonej relacji. Jednocześnie człowiek, mający doświadczenie „laboratorium wiary” staje wobec współczesnej kultury, aby dać jej ewangelicznego ducha. W ten sposób wiara jest przeżywana jako wartość, a nie jako reguła życia ${ }^{34}$.

\section{Założenia metodologiczne laboratorium}

W dokumencie Konferencji Episkopatu Włoch z 2014 roku, który wyznacza główne horyzonty dla katechezy i nauczania można odnaleźć definicję terminu „laboratorium wiary”. Określenie to nie może być rozpatrywane w kategoriach przestrzeni technicznej lub metodologicznej. Należy postrzegać ten termin jako wyrażenie określające dynamiczną rzeczywistość, w której umiejętność i kreatywność,

\footnotetext{
31 Por. DK 76, 113.

32 Por. A. Matteo, La prima generazione incredula. Il difficile rapport tra I giovani e la fede, Soveria 2017.

33 Por. A. Zavattini, Giovani e bibbia „narrattiva”. Metodi attivi e interattivi per l'incontro con la parola di Dio, Padova 2020, s. 12-18.

34 Por. F. Garelli, Piccoli atei crescono. Davvero una generazione senza Dio?, Bologna 2016, s. 20nn; Conferenza Episcopale Italiana, Il laboratorio dei talenti. Nota pastorale sul valore e la missione degli oratori nel contest dell'educazione alla vita buona del Vangelo, Roma 2013.
} 
rzemiosło i praktyka łączą się, aby za każdym razem tworzyć coś nowego w ramach istniejącej tradycji ${ }^{35}$.

Rzeczywistość laboratorium wiary przewiduje także kilka charakterystycznych punktów następujących po sobie: uważne słuchanie przeżyć ludzkich, rozpoznawanie w życiu człowieka aktywnej obecności Ducha Świętego, słuchanie słowa Bożego, obwieszczające Dobrą Nowinę, weryfikacja własnego życia w świetle doświadczenia słowa ${ }^{36}$. Aby osiągnąć ten cel, wydaje się koniecznym przestrzeganie kilku zasad metodologicznych.

\subsection{Praca zespołowa i pełne zaangażowanie wspólnoty}

We wstępie do Dyrektorium znajduje się przypomnienie, że aby wiara podlegała procesowi formacji i była przekazywana, konieczna jest obecność i zaangażowanie wspólnoty ${ }^{37}$. Potrzeba spotkania konkretnych osób, aby zaistniało laboratorium wiary i tam narodziło się doświadczenie modlitwy, liturgii i świadectwa. Katecheza jako doświadczenie mistagogiczne, ma wprowadzać wierzących w żywe doświadczenie wspólnoty chrześcijańskiej ${ }^{38}$. Kiedy jej członkowie mają do siebie pełne zaufanie, tworzą się idealne warunki do dzielenia się swoimi wątpliwościami, przemyśleniami, w poczuciu bezpieczeństwa. Każda wspólnota chrześcijańska ze swej natury winna zmierzać do dialogu ze złożonością współczesnego świata. Powinna zapraszać i przyjmować ludzi, zwłaszcza tych zagubionych ${ }^{39}$.

Dojrzała wiara, będąca owocem doświadczenia laboratorium ma charakter relacyjny i wspólnotowy. Każdy człowiek wierzący „rodzi się w matczynym łonie Kościoła"40 . Wiara wspólnoty (Kościoła) poprzedza wiarę pojedynczego człowieka. Potrzeba zatem zaangażowania i postawy służebnej tych, którzy we wspólnocie żyją, świadomie ją tworzą i czerpią radość z relacji z Bogiem. Zadaniem wspólnoty w kontekście laboratorium jest zatem uformowanie odpowiednich liderów (apostołów), którzy będą wychowywać coraz to nowych uczniów. W tym celu potrzebna jest jednak współpraca wszystkich członków wspólnoty oraz chęć dzielenia się bratnią miłością. Wspólnota nie może bać się trudnych pytań i konfrontacji z niełatwą rzeczywistością ${ }^{41}$.

Nawiązując do spotkania Jezusa z Samarytanką przy studni, katecheza sakramentalna, przeżywana w kluczu laboratorium ma wprowadzać w życie chrześcijańskie

\footnotetext{
35 Por. Conferenza Episcopale Italiana, Incontriamo Gesu. Orientamenti per l'annuncio e la catechesi in Italia, Roma 2014, n. 46, 62, 85.

36 Por. tamże.

37 Por. DK, Wstęp.

38 Por. EG 164-166; DK 2.

39 Por. DV 2; DK 12.

40 DK 21.

${ }^{41}$ Por. DK 46-49.
} 
„we wszystkich jego wymiarach, wspierając każdego w podjęciu we wspólnocie osobistej drogi odpowiedzi Bogu, który go szukał"42.

\subsection{Dynamizm i atrakcyjność procesu}

Swoistą nowością, proponowaną przez Dyrektorium o katechizacji z 2020 roku jest zastosowanie względem katechezy określenia, iż powinna być ona atrakcyjna. Członkowie całej wspólnoty, którzy przyjęli już Ewangelię i nią żyją, mają przekazywać wiarę innym w sposób żywy i dynamiczny. Proces ten ma być ciągle

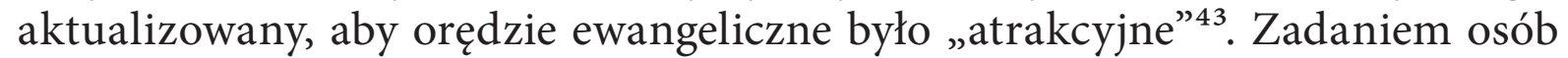
odpowiedzialnych za katechezę oraz za proces ewangelizacji jest troska o to, aby orędzie wynikające z objawienia Bożego docierało do współczesnego człowieka w sposób nie tylko zrozumiały, zgodnie z zasadami pedagogiki oraz nauk o wychowaniu i komunikacji, ale także należy dołożyć wszelkich starań, aby zachować atrakcyjność formy. W tym celu można posłużyć się rozmaitymi środkami wyrazu artystycznego: literaturą, teatrem, kinem bądź też prostymi formami, opartymi o zmysł wzroku, słuchu lub dotyku. Niekonwencjonalne środki, zachowujące godność stosowną do przekazywanych treści, mogą okazać się jedyną drogą prowadzącą do procesu poznawczego współcześnie żyjącego człowieka. Odwołując się jednak do zasady dynamizmu, należy pamiętać, że formy i metody pracy, stosowane w laboratorium, przygotowującym do przyjęcia sakramentów, nie mogą czynić kandydata jedynie widzem, ale mają sprawiać, że będąc protagonistą, podejmuje on aktywne zaangażowanie ${ }^{44}$.

Interdyscyplinarny charakter katechetyki nakazuje odnieść się do innych dyscyplin takich jak socjologia, pedagogika, psychologia czy nauki o komunikacji. W świetle tych nauk można postulować o multidymensialną koncepcję analizy religijności współczesnego człowieka. Jak zauważają R. Stark i Ch. Y. Glock, obok troski o praktyki religijne, wiedzę czy poglądy moralne, to właśnie wymiar doświadczenia wpływa w sposób skuteczny na osiągnięcie osobowych relacji z Bogiem ${ }^{45}$. Dynamizm i atrakcyjność $\mathrm{w}$ procesie przygotowania do sakramentów na drodze laboratorium wiary mogą odgrywać kluczową rolę w wywołaniu konkretnego doświadczenia, wynikającego z uczuć, postrzeżeń i doznań. Chodzi zatem o to, aby w przygotowaniu do sakramentów, zwłaszcza Eucharystii, bierzmowania i małżeństwa doprowadzić kandydatów do autentycznego doświadczenia wiary lub wręcz

\footnotetext{
42 DK 64.

43 Por. DK 134-145, 399; T. Kopiczko, „Znaki czasu” we współczesnej refleksji katechetycznej. Studium teologiczne w oparciu o Dyrektorium o Katechizacji (2020 r.), w: M.J. Tutak, T. Wielebski (red.), Pandemia jako „znak czasu” dla Kościoła w Polsce, Warszawa 2021, s. 227-242.

44 Por. DK 212; S. Kulpaczyński, Jaki katecheta dla współczesnej młodzieży, w: S. Kulpaczyński (red.), Katecheza młodzieży, Lublin 2003, s. 99-119.

45 Por. R. Szauer, Wymiary osobistych doświadczeń religijnych młodzieży w społeczeństwie doznań, w: A. Draguła, Młodzież wobec wiary i powołania, Szczecin 2020, s. 73-98.
} 
uczuciowej tęsknoty za Bogiem. O ile przecież wychowanie religijne ma zmierzać do rozwoju wiary, to na poszczególnych etapach życia na nowo powinno nabierać nowej dynamiki oraz korelować $\mathrm{z}$ pragnieniami dojrzewającego człowieka ${ }^{46}$.

\subsection{Doświadczenie miłości (źródłem permanentnego stanu nawrócenia i misji)}

Kolejnym istotnym elementem w metodologii laboratorium jest doświadczenie miłości. Dyrektorium o katechizacji już na samym początku zakłada, że katecheza ma wprowadzać wierzącego „w żywe doświadczenie wspólnoty chrześcijańskiej" ${ }^{47}$. Z kolei proces głoszenia i rozpowszechniania Ewangelii w całym świecie ma kierować się miłością, przenikać i przekształcać porządek świata, wprowadzać w wiarę i życie chrześcijańskie. Dzieje się to na drodze katechezy, przygotowania do sakramentów, świadectwa i doświadczenia braterstwa oraz miłości. Założenie to wydaje się być szczególnie istotne wobec wszystkich wyzwań, które przynosi świat cyfrowy ${ }^{48}$. Proces nawrócenia tych, którzy wybrali Chrystusa oraz pójście za Nim jest o wiele bardziej skuteczny i owocny, kiedy jest przeżywany w klimacie wspólnoty, którą ożywia „dar komunii”49.

Swoista „wędrówka duchowa”, którą ma być przygotowujące do sakramentów laboratorium wiary zakłada nie tylko wyrzeczenie się grzechu, ale także chrześcijańską radość. Uczeń Chrystusa może być gotowy, aby wyznawać wiarę w sposób radosny, o ile jest zakorzeniony we wspólnocie Kościoła, który żyje miłością ${ }^{50}$. Doświadczenie to nie jest pozbawione pierwiastka rozumowego ${ }^{51}$, zakłada swoisty paralelizm wiary i rozumu. O ile jednak laboratorium $\mathrm{w}$ przygotowaniu do sakramentów ma być czasem i miejscem spotkania z Chrystusem, to nie może być pozbawione autentycznego doświadczenia miłości. Jak zakłada Dyrektorium, katecheza oparta o zasadę lex credendi i lex orandi jest właściwa, o ile odnosi się do stylu życia wierzących jako świadectwa miłości. To właśnie ono czyni orędzie ewangeliczne wiarygodnym w oczach człowieka ${ }^{52}$. Także akt żywej wiary rodzi się z miłości ${ }^{53}$. Wiara zbudowana na fundamencie miłości, zgodnie z biblijną zasadą, prowadzi do coraz głębszego poznania Chrystusa, obecnego we wspólnocie

\footnotetext{
46 Por. DK 2-3; EG 166; K. Wolsza, Doświadczenie religijne i możliwość jego kształtowania, w: R. Chałupniak, J. Kostorz, W. Spyra (red.), Aktywizacja w katechezie - szansa czy zagrożenie?, Opole 2002, s. 11-23; J. Pawlik, Religia przeżywana, „Roczniki Teologiczne” 66(9), s. 79-91; S. Sztajer, Formy ucieleśnienia w religii przeżywanej, „Przegląd religioznawczy” 1(2021)279, s. 159-167.

47 DK 2.

48 Por. R. Cekiera, Cyfrowi apateiści? Szkic do socjologicznego portretu religijności młodych Polaków, w: A. Draguła (red.), Młodzież wobec wiary i powołania, Szczecin 2020, s. 49-72.

49 Por. DK 31.

50 Por. AG 13; DK 34.

51 Por. DK 97.

52 Por. tamże, Wstęp.

53 Por. DK 4.
} 
Kościoła. Wprowadza wierzącego do życia chrześcijańskiego, a w odpowiednich momentach uzdalnia go do przyjęcia kolejnych sakramentów ${ }^{54}$.

Należy również pamiętać, że miłość jest kluczem do interpretacji wspólnoty Kościoła. Kościół w największym swoim misterium jest komunią ludzi z osobami Trójcy Świętej oraz ludzi pomiędzy sobą. Mówiąc inaczej, jest tajemnicą miłości przyjętej i podarowanej. Zatem praktykowanie miłości w uczynkach i słowach powinno mieć wymiar widzialny i stanowić naczelną zasadę w przygotowaniu do sakramentów, które w intymnie duchowy sposób prowadzą do zjednoczenia $\mathrm{z}$ Bogiem $^{55}$.

\subsection{Weryfikacja}

Jednym z istotnych postulatów dotyczących katechezy chrześcijańskiego wtajemniczenia, zawartych w Dyrektorium o katechizacji, jest dążenie do zintegrowanego rozumienia procesów chrześcijańskiego przeżywania kolejnych sakramentów. Domaga się to nieustannej weryfikacji praktyki ${ }^{56}$. Dokument zaznacza, że w niektórych miejscach świata poszczególne kościoły partykularne podjęły już wysiłek weryfikacji w celu dokonania odnowy pastoralnej ${ }^{57}$. Taka postawa wymaga jednak od odpowiedzialnych za proces katechezy odpowiedzialności i pokory. W końcowej fazie przygotowania do sakramentów, zwłaszcza na drodze laboratorium wiary, należy dokonać precyzyjnej weryfikacji dotychczasowych postępowań. Zgodnie $\mathrm{z}$ zasadami postępowania pedagogicznego celem tego działania nie jest jedynie krytyka, lecz wyciągnięcie odpowiednich wniosków. Być może rodzi się potrzeba określenia dotychczasowych założeń i celów w sposób bardziej precyzyjny.

Podstawowym sposobem weryfikacji w przygotowaniu do sakramentów na drodze laboratorium wiary będą owoce, które wydadzą poszczególne osoby. W prosty sposób obserwacji można dostrzec czy po przyjęciu sakramentów, zwłaszcza w odniesieniu do Eucharystii, bierzmowania i małżeństwa, osoby te nadal uczestniczą w życiu wspólnoty Kościoła, czy angażują się w różnego rodzaju działania lub posługi, podejmowane przez wspólnotę, czy też w sposób jedynie formalny przyjęły sakrament i nie kontynuują formacji. Kluczem do weryfikacji może być odniesienie danej osoby do sakramentu Eucharystii, jego życie duchowe i modlitewne oraz konkretna praktyka miłości, wyrażona w czynach moralnych. Należy przy tym pamiętać, jak zauważa Dyrektorium, że w kościele „ochrzczony poruszany

\footnotetext{
54 Por. tamże, 11-15; T. Kopiczko, Biblijne owoce Ducha Świętego (Ga 5,22-23) na drodze do dojrzałej wiary w katechezie, „Verbum Vitae” 37(2020), s. 257-270.

55 Por. F. Ardusso, Miłość (caritas), w: J. Gevaert (red.), Słownik katechetyczny, Warszawa 2007, s. 601-606.

56 Por. DK 70; G. Zaniello, Verifica, w: J.M. Prellezo (red.), Dizionario di scienze dell'educazione, Roma 2008, s. 1241-1243.

57 Por. DK 297; M. Madej-Babula, Wychowanie religijne w kontekście pedagogiki, w: A. Hajduk, J. Mółka (red.), Pedagogika wiary, Kraków 2007, s. 55-72.
} 
zawsze jest przez Ducha Świętego, umacniany sakramentami, modlitwą i praktyką miłości oraz wspomagany wielorakimi formami stałego wychowania wiary" ${ }^{15}$. To wszystko ma prowadzić do głębokiego zjednoczenia z Chrystusem i podjęcia wysiłku naśladowania.

Dokonując weryfikacji, należy jednak zachować maksymalną ostrożność względem osób podejmujących formację w laboratorium wiary. Jak zauważa Dyrektorium o katechizacji, proszący o łaskę sakramentu może być jej niegodny lub może ją zmarnować, gdyż brakuje mu autentycznego doświadczenia wiary i zażyłej relacji z Bogiem. Wina jednak może leżeć zarówno po stronie kandydata, jak i po stronie tych, którzy prowadzą przygotowanie. Formalne głoszenie, ograniczone jedynie do prezentacji pojęć związanych z wiarą, nie pozwala właściwie zrozumieć istoty sakramentu. Taka forma przygotowania nie otwiera także na perspektywę życia w relacji z Jezusem Chrystusem. Wtedy można mówić o sytuacji zawinionej przez tych, którzy są odpowiedzialni za proces przygotowania do sakramentów ${ }^{59}$.

\section{Zakończenie}

Kluczem do realizacji wyżej przedstawionych założeń jest współpraca wszystkich członków wspólnoty Kościoła. Czymś oczywistym jest, że w głównej mierze postulat laboratorium wiary w przygotowaniu do sakramentów odnosi się do kapłanów i katechetów. Proponowana forma przygotowania wymaga jednak nowości nie tylko od strony formalnej, ale także w procesie stworzenia autentycznych warunków komunii w wymiarze wertykalnym i horyzontalnym. Wszyscy ochrzczeni oraz ci, którzy przyjęli sakrament bierzmowania mogą w sposób aktywny wspierać to działanie, bądź to na drodze osobistego zaangażowania się, bądź na drodze wsparcia modlitewnego.

Wyzwaniem względem całej wspólnoty jest stworzenie takiej atmosfery, aby laboratorium wiary stało się przestrzenią życzliwości i dialogu. Osoby, które pragną przyjąć kolejny sakrament w swoim życiu, poprzez działanie wspólnoty Kościoła powinny dojrzewać w swoim doświadczeniu spotkania Boga, który jest miłością. Poszukiwanie Boga i relacji z Nim powinno zatem odbywać się na poziomie intelektu oraz emocji i przeżyć, pozwalających na doświadczenie bliskości braterskiej Boga i drugiego człowieka. Słowa objawienia oraz prawd katechizmowych nie mogą być jedynie doktryną, a powinny stać się prawdą głoszoną, przyjętą oraz przeżywaną. Zatem laboratorium powinno być miejscem doświadczenia relacji,

\footnotetext{
58 DK 35.

59 Por. DK 56; Konferencja Episkopatu Polski, Podstawa programowa katechezy Kościoła katolickiego w Polsce, Częstochowa 2018, s. 53-57; Komisja Wychowania Katolickiego Konferencji Episkopatu Polski, Program nauczania religii rzymskokatolickiej w przedszkolach i szkołach, Częstochowa 2018, s. 85-86.
} 
stawiania pytań i poszukiwania odpowiedzi, dotyczących sensu życia oraz wiary. Winno być także miejscem spotkania z żywym i osobowym Bogiem.

Słowa kluczowe: laboratorium wiary, katecheza, przygotowanie do sakramentów.

\section{Summary}

The aim of this article is to deliberate on the issue of sacramental catechesis, implemented according to a "lab strategy”. This aim is accomplished in the course of presenting a contemporary catechetical context, explaining the meaning of "faith lab" and presenting the fundamental methodological assumptions. The latest catechetical documents and papal teachings based on the principles of conciliar renewal constitute the main source of this deliberation.

Keywords: Faith lab, catechesis, preparation for sacraments.

\section{Riassunto}

Lo scopo di questo articolo si focalizza nella riflessione sul tema della catechesi sacramentale, attuata nella „strategia di laboratorio”. Questo obiettivo si raggiunge presentando il contesto catechistico contemporaneo, spiegando il significato del termine "laboratorio della fede" e presentando sinteticamente i presupposti metodologici di base. La principale fonte di riflessione sono gli ultimi documenti catechetici e l'insegnamento dei pontefici che mettono in atto i principia del rinnovamento conciliare.

Parole chiavi: laboratorio della fede, catechesi, preparazione ai sacramenti.

\section{Bibliografia}

Ardusso F., Miłość (caritas), w: Gevaert J. (red.), Słownik katechetyczny, Warszawa 2007, s. 601-606.

Benedykt XVI, Przedmowa, w: Jezus z Nazaretu, cz. 1, Kraków 2007.

Blachnicki F., Sympatycy czy chrześcijanie?, Kraków 2008.

Cekiera R., Cyfrowi apateiści? Szkic do socjologicznego portretu religijności młodych Polaków, w: Draguła A. (red.), Młodzież wobec wiary i powołania, Szczecin 2020, s. 49-72.

Conferenza Episcopale Italiana, Il laboratorio dei talenti. Nota pastorale sul valore e la missione degli oratori nel contest dell'educazione alla vita buona del Vangelo, Roma 2013.

Conferenza Episcopale Italiana, Incontriamo Gesu. Orientamenti per l'annuncio e la catechesi in Italia, Roma 2014.

Congar Y., Prawdziwa i fałszywa reforma w Kościele, Kraków 2001.

Dunlap J., Practical catechesis, New York 2001.

Fisichella R., Nowe dyrektorium o katechizacji: więcej ewangelizacji, w: https://www.vaticannews.va/pl/watykan/news/2020-06/dyrektorium-o-katechizacji.html, [dostęp 14.06.2021].

Franciszek, Adhortacja apostolska Evangelii gaudium (24 listopada 2013).

Garelli F., Piccoli atei crescono. Davvero una generazione senza Dio?, Bologna 2016.

Hill B. R., Key Dimensions of Religious Education, Winona Minnesota 1988. 
Jan Paweł II, Nie lękajcie się zawierzyć Chrystusowi. Przemówienie wygłoszone podczas czuwania modlitewnego w Tor Vergata 19 sierpnia 2000, w: https://opoka.org.pl/biblioteka/W/WP/jan_pawel_ii/przemowienia/tor_vergata_19082000.html, [dostęp 14.06.2021]. Katechizm Kościoła Katolickiego (11 października 1992).

Komisja Wychowania Katolickiego Konferencji Episkopatu Polski, Program nauczania religii rzymskokatolickiej w przedszkolach i szkołach, Częstochowa 2018.

Konferencja Episkopatu Polski, Podstawa programowa katechezy Kościoła katolickiego w Polsce, Częstochowa 2018.

Kopiczko T., „Znaki czasu” we współczesnej refleksji katechetycznej. Studium teologiczne w oparciu o Dyrektorium o Katechizacji (2020 r.), w: Tutak M. J., Wielebski T. (red.), Pandemia jako „znak czasu” dla Kościoła w Polsce, Warszawa 2021, s. 227-242.

Kopiczko T., Biblijne owoce Ducha Świętego (Ga 5,22-23) na drodze do dojrzałej wiary w katechezie, „Verbum Vitae” 37(2020), s. 257-270.

Körner B., Fusione di testimonianza e testimone nella comunione dei testimoni. Conoscenza nella fede a spiritualità della comunione, w: M. Sodi, Il metodo teologico. Tradizione, innovazione, comunione in Cristo, Citta del Vaticano 2008, s. 381-395.

Kulpaczyński S., Jaki katecheta dla współczesnej młodzieży, w: Kulpaczyński S. (red.), Katecheza młodzieży, Lublin 2003, s. 99-119.

Madej-Babula M., Wychowanie religijne w kontekście pedagogiki, w: Hajduk A., Mółka J. (red.), Pedagogika wiary, Kraków 2007, s. 55-72.

Matteo A., La prima generazione incredula. Il difficile rapport tra I giovani e la fede, Soveria 2017.

Mendyk M., Fenomen Światowych Dni Młodzieży - świadectwo ze spotkania młodych w Madrycie, „Wrocławski Przegląd Teologiczny” 20(2012)1, s. 123-134.

Pagola J. A., Percorsi di evangelizzazione, Bologna 2018.

Papieska Rada ds. Krzewienia Nowej Ewangelizacji, Dyrektorium o katechizacji (23 marca 2020).

Paweł VI, Adhortacja apostolska Evangelii nuntiandi (8 grudnia 1975).

Paweł VI, Encyklika Ecclesiam suam (6 sierpnia 1964).

Pawlik J., Religia przeżywana, „Roczniki Teologiczne” 66(9), s. 79-91.

Rojek M., Ecclesia semper reformanda, „Resovia Sacra. Studia Teologiczno-Filozoficzne Diecezji Rzeszowskiej” 3 (1996), s. 25-37.

Roselli M., Io acolgo te. Primolaboratorio della fede, w: „Rivista di Pastorale Liturgica” 1(2017), s. 42-45.

Sobór Watykański II, Dekret o działalności misyjnej Kościoła Ad gentes (7 grudnia 1965).

Sobór Watykański II, Konstytucja dogmatyczna o Kościele Lumen gentium (21 listopada 1964).

Sobór Watykański II, Konstytucja o Objawieniu Bożym Dei Verbum (18 listopada 1965).

Szauer R., Wymiary osobistych doświadczeń religijnych młodzieży w społeczeństwie doznań, w: Draguła A., Młodzież wobec wiary i powołania, Szczecin 2020, s. 73-98.

Sztajer S., Formy ucieleśnienia w religii przeżywanej, „Przegląd religioznawczy” 1(2021)279, s. $159-167$. 
Wolsza K., Doświadczenie religijne i możliwość jego kształtowania, w: Chałupniak R., Kostorz J., Spyra W. (red.), Aktywizacja w katechezie - szansa czy zagrożenie?, Opole 2002, s. 11-23.

Zaniello G., Verifica, w: Prellezo J.M. (red.), Dizionario di scienze dell'educazione, Roma 2008, s. 1241-1243.

Zavattini A., Giovani e bibbia „narrattiva”. Metodi attivi e interattivi per l'incontro con la parola di Dio, Padova 2020.

\section{O autorach}

Ks. Tomasz KOPICZKO - prezbiter diecezji ełckiej, doktor nauk teologicznych, pracownik naukowo-dydaktyczny Uniwersytetu Kardynała Stefana Wyszyńskiego w Warszawie oraz WSD w Ełku, członek Stowarzyszenia Katechetyków Polskich oraz Towarzystwa Naukowego Franciszka Salezego. Zakres swoich zainteresowań badawczych koncentruje wokół tematów związanych z nową ewangelizacją, teologią katechezy, eklezjologią i nowymi środkami komunikacji.

Paulina OKŁA - magister teologii, studentka prawa. Nauczyciel w szkole podstawowej. Zakres swoich zainteresowań badawczych koncentruje wokół tematów związanych z biblistyką, katechetyką, prawem i muzyką. 